\title{
Ethnobotany of traditional medicine in Dayak Jangkang Tribe, Sanggau District, West Kalimantan, Indonesia
}

\author{
MARKUS IYUS SUPIANDI ${ }^{1, \bullet}$, BENEDIKTUS EGE ${ }^{1}$, HENDRIKUS JULUNG ${ }^{1}$, SITI ZUBAIDAH $^{2, \bullet \bullet}$, \\ SUSRIYATI MAHANAL ${ }^{2}$ \\ ${ }^{1}$ Program of Biology Education, STKIP Persada Khatulistiwa Sintang. J1. Pertamina Km 4, Sengkuang, Sintang 78614, West Kalimantan, Indonesia. Tel. \\ +62858-4517-6941, `email: msupiandi@gmail.com \\ ${ }^{2}$ Program of Biology Education, Universitas Negeri Malang. Jl. Semarang, Malang 65145, East Java, Indonesia. Tel. +62813-3443-5234, \\ vemail: siti.zubaidah.fmipa@um.ac.id
}

Manuscript received: 12 November 2021. Revision accepted: 21 November 2021.

\begin{abstract}
Supiandi MI, Ege B, Julung H, Zubaidah S, Mahanal S. 2021. Ethnobotany of traditional medicine in Dayak Jangkang Tribe, Sanggau District, West Kalimantan, Indonesia. Biodiversitas 22: 5417-5424. The Dayak Jangkang tribe has local knowledge about the use of medicinal plants that have been going on for a long time. Unfortunately, the local knowledge of the Dayak Jangkang tribe is currently threatened to disappear because it is delivered orally; there are no written documents and a wasteful lifestyle. The study aimed to document traditional medicinal plants that are utilized by the Dayak Jangkang tribe. The research approach used was qualitative descriptive using the field survey. The study interviewed three informants categories, i.e., the main informant (one customary chairman), key informant (one village head), and recommended informant (eight people who were knowledgeable about medicinal plants). The data were obtained through in-depth interviews and participatory observations. Data analysis used qualitative descriptive. The study got 40 plants that are used for traditional medicine with Zingiberaceae as the most used family. The parts of plants used by the Dayak Jangkang tribe for treatments were roots, bulbs, rhizomes, stems, bark, banana hump, fruit, fruit skins, leaves, fruit, and seeds. The mode of preparation is still considered simple.
\end{abstract}

Keywords: Dayak, Jangkang, local knowledge, medicinal, traditional

\section{INTRODUCTION}

West Kalimantan is the fourth largest province in Indonesia, with a population dominated by Dayak (Sardana et al. 2011; Supiandi et al. 2019). The Dayak tribe in West Kalimantan consists of 151 sub-ethnics (Alloy et al. 2008). One of them is the Dayak Jangkang tribe located in Jangkang Village, Balai Sebut Sub-district, Sanggau District. The Dayak Jangkang tribe still coexists with the forest and has a good interaction pattern with the surrounding environment. Dayak Jangkang people who live around the forest still maintain customs and traditions in utilizing forest products. Forests provide resources that the community can use as food, buildings, craft materials, natural dyes, cosmetics, and medicine (Setyawan 2010; Takoy et al. 2013; Fadilah et al. 2015; Roslinda 2016; Andesmora et al. 2017; Nurcahyani et al. 2019; Supiandi et al. 2019). It is also true that the Dayak Jangkang people use plants in the forest to meet their daily needs.

Customs and traditions in utilizing forest natural resources by certain tribes, including the Dayak Jangkang tribe, are local wisdom. Local wisdom can be interpreted as a view of life, knowledge, and various life strategies in activities carried out by local communities to answer multiple problems in meeting daily life needs (Suparmini et al. 2013). Anand et al. (2021) mentioned local wisdom is a specific practice developed in ancient times and maintained from generation to generation through knowledge, essentially limited to certain tribes, local communities, or family lineages. Sartini (2004) also mentioned the function of local wisdom, namely: (i) for the conservation and preservation of natural resources, (ii) serves for the development of culture and science. Local knowledge related to culture for biodiversity conservation is a repository of alternative options that safeguard cultural and biological diversity (Virginia 2006). One form of local wisdom of the Dayak Jangkang tribe uses plant values as traditional medicine, food, clothing, boards, customary rituals, natural dyes, and natural pesticides.

However, socio-cultural changes threaten the local wisdom of the people in certain tribes, including the Dayak Jangkang tribe, about using plant values in everyday life. First, the threat can be in the form of consumptive forces that can erode the norms of local wisdom in the community (Suhartini 2009). Second, delivery of information about the use of plant values using only verbal communication (Yusro et al. 2014; Julung et al. 2018; Nurcahyani et al. 2019; Supiandi et al. 2019; Supiandi and Leliavia 2020), and has no written documentation (Gurib-Fakim 2006; Namsa et al. 2011; Rashid et al. 2018). Third, foreign cultural influence and forest degradation due to shifting cultivation, plantations, and forest fires (Kustiawan 2007; Setyawan 2010).

The need to study ethnobotany and local wisdom (local knowledge) becomes essential. Ethnobotanical studies play a role not only to uncover local knowledge but also have many benefits, including (i) plant conservation (Byg and Baslev 2001; Muthu et al. 2006; De la Torre et al. 2012; 
Sop et al. 2012; Kewessa et al. 2015; Marin et al. 2015; Nahdi et al. 2016; Akgul et al. 2018), (ii) cultural conservation, recognition of local people's rights, traditional wisdom, and traditional knowledge (Albuquerque et al. 2006; Ajesh et al. 2012; Marin et al. 2015). The general public does not widely know Dayak Jangkang people's knowledge about medicinal plants, so research studies must be informed. This study describes local wisdom related to the ethnobotany of medicinal plants in the Dayak Jangkang tribe.

\section{MATERIALS AND METHODS}

\section{Study area}

The study was conducted from August 2021 to September 2021 in Kobang hamlet, Jangkang Benua Village, Sanggau District, West Kalimantan Province, Indonesia. The distance to the city of the Jangkang Subdistrict is $11 \mathrm{~km}$. The road body is not entirely concrete, with a width that can only be traversed by motorcycles with hilly contours. Thus agricultural products cannot be marketed effectively. The air temperature in the Kobang hamlet ranges from 18 to $20^{\circ} \mathrm{C}$ due to the hills surrounded. The hamlet consists of 48 families with 177 inhabitants comprised of 102 men and 75 women. The majority of the people are indigenous Dayak Jangkang and generally work as rice and vegetable farmers (Direktorat Jenderal Kependudukan dan Pencatatan Sipil 2020).

\section{Data collection}

The study employed a qualitative descriptive approach. This approach was used because the data obtained were descriptive in written and oral words from the Dayak Jangkang people who understand plant species for traditional medicine. We collected field data related to the medicinal plant used by the Dayak Jangkang tribe. Data were obtained from informants, events or activities, places or locations, objects, images, and recordings, as well as written or unwritten documents. The study consisted of three informants: the main informant, the key informant, and the recommended informant. The purposive sampling techniques determined the main informant. Key and recommended informants were selected using snowball sampling. Snowball sampling is an informant selection technique from previous informant recommendations (Bernard 2002). The total number of informants was ten people consisting of one customary chairman (main informant), one village head (key informant), and eight people who were willing and knowledgeable about medicinal plants (informants recommendations). We received the information through in-depth interviews. First, in-depth interviews were obtained by asking open-ended questions that allowed informants to provide broad answers (Kabir 2016). Questions were directed to reveal the life of the Dayak Jangkang community about the medicinal plants used in everyday life. The next stage continued with participatory observation, where informants and we conducted plants documentation in the Bengkawan forest and then verified using plants of the world online (POWO 2021).

\section{Data analysis}

Medicinal plants data were analyzed using qualitative descriptive with several stages: data collection, data reduction, presentation of data, and withdrawal of conclusions based on Miles and Huberman (2007).

\section{RESULTS AND DISCUSSION}

\section{Results}

The study obtained 40 plant species used as traditional medicine in the Dayak Jangkang tribe community, presented in Table 1.

Table 1 showed that the Dayak Jangkang people use plants as traditional medicine in everyday life. The community used as many as 40 plant species to treat various diseases. The use parts were roots, rhizomes, stems, leaves, seeds, and fruits. However, the Dayak Jangkang people still employed a simple way of processing plants for traditional medicine.

\section{Discussion}

Based on in-depth interviews and participatory observations with respondents in the Dayak Jangkang tribe community obtained as many as 40 plant species were used as traditional medicine. The medicinal plants were obtained around the forest near the housing of the Dayak Jangkang tribe. The discovery of various species of medicinal plants shows that the community area still has a naturalness. According to Purwoko (2004), forests have the potential as a source of medicine. According to Simamora (2018), forests are natural resources with many benefits, including ecology, socio-culture, economy, and medicine.

The Dayak Jangkang tribe use medicinal plants derived from the families of Zingiberaceae (7 species), Lamiaceae (4 species), Piperaceae (3 species), Poaceae (3 species), Araceae (2 species), Arecaceae (2 species), Fabaceae (2 species), Lamiaceae (2 species), Myrtaceae (2 species), Rubiaceae ( 2 species), and the following are one species each, including Acoraceae, Annonaceae, Apocynaceae, Caricaceae, Compositae, Convolvulaceae, Cyperaceae, Dilleniaceae, Phyllanthaceae, Leguminosae, Iridaceae, Meliaceae, Malvaceae, and Musaceae. The most widely used family was Zingiberaceae. The family has many benefits for medicinal and seasoning dishes. Previous studies revealed that Zingiberaceae could be used for drugs, dyes, perfumes, and herbs (Sirirugsa 1998; Habsah et al. 2000). Laokor and Juntachai (2021) mentioned that the family has long been used in traditional medicine to treat fungal skin disorders. Zingiberaceae family contains flavonoids, saponins, and essential oils that serve as antioxidants, antibacterial, and antiinflammatory (Ozaki et al. 1991; Jitoe et al. 1994; Habsah et al. 2000; TPC 2012). 
Table 1. The list of medicinal plants used by Dayak Jangkang communities, Sanggau District, West Kalimantan, Indonesia

\begin{tabular}{|c|c|c|c|c|c|}
\hline Family & Local name & Scientific name & Part used & Mode of preparation & Use \\
\hline Acoraceae & Jerongo & Acorus calamus $\mathrm{L}$. & Rhizome & $\begin{array}{l}\text { Mashed, mixed with } \\
\text { water, drunk }\end{array}$ & $\begin{array}{l}\text { Antidotes to poison and treat } \\
\text { cough }\end{array}$ \\
\hline Annonaceae & $\begin{array}{l}\text { Nangka } \\
\text { belanda }\end{array}$ & Annona muricata $\mathrm{L}$. & $\begin{array}{l}\text { Leaves } \\
\text { and seeds }\end{array}$ & $\begin{array}{l}\text { The leaves are boiled and } \\
\text { drunk. Seeds are ground } \\
\text { mixed with water and } \\
\text { drunk. }\end{array}$ & $\begin{array}{l}\text { Lower cholesterol and treat } \\
\text { complex bowel movements }\end{array}$ \\
\hline Apocynaceae & Jita & $\begin{array}{l}\text { Alstonia scholaris (L.) } \\
\text { R. Br. }\end{array}$ & Leaves & Pounded, drunk & Treating diarrhea \\
\hline \multirow[t]{2}{*}{ Araceae } & Tungun & $\begin{array}{l}\text { Homalomena occulta } \\
\text { (Lour.) Schott }\end{array}$ & $\begin{array}{l}\text { Tuber, } \\
\text { leaves }\end{array}$ & Pounded, taped & $\begin{array}{l}\text { Treating the bite of a } \\
\text { venomous animal (centipede) }\end{array}$ \\
\hline & $\begin{array}{l}\text { Kudok } \\
\text { betawi }\end{array}$ & $\begin{array}{l}\text { Xanthosoma } \\
\text { sagittifolium (L.) } \\
\text { Schott. }\end{array}$ & Tuber & Boiled, eaten & Decrease hypertension \\
\hline \multirow[t]{2}{*}{ Arecaceae } & Buntan ijau & Cocos nucifera $\mathrm{L}$. & Fruit & $\begin{array}{l}\text { Green coconut fruit that } \\
\text { has been used as oil } \\
\text { mixed with onions } \\
\text { "Dayak" that have been } \\
\text { mashed then applied }\end{array}$ & Nourishing hair \\
\hline & Uwai & Areca catechu $\mathrm{L}$. & Fruit & Boiled, drunk & Treating vaginal discharge \\
\hline Caricaceae & Stela & Carica papaya $\mathrm{L}$. & Leaves & Boiled, drunk & Treating malaria fever \\
\hline Compositae & $\begin{array}{l}\text { Lidah } \\
\text { kambing }\end{array}$ & Elephantopus scaber L. & Leaves & Boiled, drunk & $\begin{array}{l}\text { Treating malaria, headaches } \\
\text { accompanied by fever chills }\end{array}$ \\
\hline Convolvulaceae & Kidong & $\begin{array}{l}\text { Ipomoea batatas }(\mathrm{L} .) \\
\text { Lam. }\end{array}$ & Leaves & $\begin{array}{l}\text { Pounded, affixed to the } \\
\text { wounded part }\end{array}$ & Treating burns \\
\hline Cyperaceae & Siet & Cyperus longus $\mathrm{L}$. & Leaves & Pounded, smeared & $\begin{array}{l}\text { Treating minor injuries from } \\
\text { sharp objects }\end{array}$ \\
\hline Dilleniaceae & Pangan & $\begin{array}{l}\text { Dillenia suffruticosa } \\
\text { (Griff.) Martelli. }\end{array}$ & Leaves & Boiled, drunk & $\begin{array}{l}\text { Facilitate breast milk and } \\
\text { postpartum recovery }\end{array}$ \\
\hline Fabaceae & Golinggang & Cassia alata $\mathrm{L}$. & Leaves & Pounded, smeared & $\begin{array}{l}\text { Treating ringworm, scabies, } \\
\text { and Pityriasis versicolor }\end{array}$ \\
\hline Iridaceae & $\begin{array}{l}\text { Bawang } \\
\text { ruma }\end{array}$ & $\begin{array}{l}\text { Eleutherine americana } \\
\text { (Aubl.) Merr. ex } \\
\text { K.Heyne. }\end{array}$ & Tuber & $\begin{array}{l}\text { Boiled and drunk or } \\
\text { ground, taped with added } \\
\text { green coconut oil }\end{array}$ & Treating gout \\
\hline \multirow[t]{4}{*}{ Lamiaceae } & $\begin{array}{l}\text { Kumis } \\
\text { kucing }\end{array}$ & $\begin{array}{l}\text { Orthosiphon stamineus } \\
\text { Benth. }\end{array}$ & Leaves & Boiled, drunk & $\begin{array}{l}\text { Treating kidney pain and } \\
\text { difficulty defecating }\end{array}$ \\
\hline & Berbuas & $\begin{array}{l}\text { Premna cordifolia } \\
\text { Roxb. }\end{array}$ & Leaves & Boiled, drunk & Treating body odor \\
\hline & Ngarut & Vitex pinnata $\mathrm{L}$. & Leaves & Pounded, taped & Treating headaches \\
\hline & Selasih & Ocimum basilicum $\mathrm{L}$. & $\begin{array}{l}\text { Leaves, } \\
\text { flower }\end{array}$ & Pounded, smeared & $\begin{array}{l}\text { Treating Pityriasis versicolor, } \\
\text { scabies, and ringworm }\end{array}$ \\
\hline Leguminosae & $\begin{array}{l}\text { Rohtak } \\
\text { borobuh }\end{array}$ & $\begin{array}{l}\text { Psophocarpus } \\
\text { tetragonolobus (L.) DC. }\end{array}$ & Fruit & $\begin{array}{l}\text { Pounded, mixed with } \\
\text { water, dripped }\end{array}$ & $\begin{array}{l}\text { Treating ears that secrete } \\
\text { white or yellow fluid }\end{array}$ \\
\hline Meliaceae & Rosat & $\begin{array}{l}\text { Lansium domesticum } \\
\text { Corrêa. }\end{array}$ & $\begin{array}{l}\text { Root, } \\
\text { leaves, } \\
\text { stem skin, } \\
\text { fruit skin, } \\
\text { and seeds }\end{array}$ & Boiled, drunk & $\begin{array}{l}\text { Treating headaches } \\
\text { accompanied by malaria fever }\end{array}$ \\
\hline Malvaceae & $\begin{array}{l}\text { Pota } \\
\text { pongayoh }\end{array}$ & Sida rhombifolia $\mathrm{L}$. & Leaves & Pounded, pasted & Treating sprains \\
\hline Musaceae & Koding & Musa textilis Née. & $\begin{array}{l}\text { Hump, } \\
\text { stem, } \\
\text { leaves }\end{array}$ & $\begin{array}{l}\text { Pounded, take water, and } \\
\text { drop it on the wounded } \\
\text { body }\end{array}$ & $\begin{array}{l}\text { Stop bleeding from sharp } \\
\text { object wounds and speed } \\
\text { healing }\end{array}$ \\
\hline \multirow[t]{2}{*}{ Myrtaceae } & Bungkang & $\begin{array}{l}\text { Syzygium polyanthum } \\
\text { (Wight.) Walp. }\end{array}$ & Leaves & $\begin{array}{l}\text { Pounded mixed with } \\
\text { water, and the water is } \\
\text { dripped on the bodies that } \\
\text { are sick. }\end{array}$ & Treating scabs on the skin \\
\hline & Risak & $\begin{array}{l}\text { Rhodomyrtus tomentosa } \\
\text { (Aiton.) Hassk. }\end{array}$ & Leaves & Mashed, taped & Treating wounds and scabs \\
\hline Phyllanthaceae & Cangkok & $\begin{array}{l}\text { Sauropus androgynus } \\
\text { (L.) Merr. }\end{array}$ & Leaves & Pounded, smeared & $\begin{array}{l}\text { Treating whitish and red } \\
\text { diseases of the baby's mouth } \\
\text { and tongue }\end{array}$ \\
\hline
\end{tabular}




\begin{tabular}{|c|c|c|c|c|c|}
\hline \multirow[t]{3}{*}{ Piperaceae } & Boik & Piper betle $\mathrm{L}$. & Leaves & $\begin{array}{l}\text { Boiled, water vapor is } \\
\text { directed to blurred eyes or } \\
\text { eyes soaked in boiled } \\
\text { water that has cooled }\end{array}$ & Treating blurred eyes \\
\hline & $\begin{array}{l}\text { Boik } \\
\text { remaung }\end{array}$ & $\begin{array}{l}\text { Piper crocatum Ruiz \& } \\
\text { Pav. }\end{array}$ & Leaves & Pounded, drunk/pasted & $\begin{array}{l}\text { Treating } \\
\text { jaundice/liver/hepatitis }\end{array}$ \\
\hline & Sahang & Piper nigrum $\mathrm{L}$. & Fruit & $\begin{array}{l}\text { Mashed, mixed with } \\
\text { water, drunk }\end{array}$ & Treating colds \\
\hline \multirow[t]{3}{*}{ Poaceae } & Lalang & $\begin{array}{l}\text { Imperata cylindrica (L.) } \\
\text { Raeusch. }\end{array}$ & Root & Pounded, smeared & Treating the throat \\
\hline & Sorai & $\begin{array}{l}\text { Cymbopogon citratus } \\
\text { (DC.) Stapf. }\end{array}$ & Stem & Chopped, boiled, drunk & Treating cough \\
\hline & Sorai wangi & $\begin{array}{l}\text { Cymbopogon nardus } \\
\text { (L.) Rendle. }\end{array}$ & $\begin{array}{l}\text { Stem, } \\
\text { leaves }\end{array}$ & Pounded, smeared & Treating colds \\
\hline \multirow[t]{2}{*}{ Rubiaceae } & Engkudu & Morinda citrifolia $\mathrm{L}$. & Leaves & Boiled, drunk & Treating yellow pain \\
\hline & Tobang & $\begin{array}{l}\text { Psychotria viridis Ruiz } \\
\text { \& Pav. }\end{array}$ & Leaves & Boiled, drunk & Treating stomach pain \\
\hline \multirow[t]{7}{*}{ Zingiberaceae } & Bongah & $\begin{array}{l}\text { Curcuma domestica } \\
\text { Valeton. }\end{array}$ & Rhizome & Mashed, boiled, drunk & $\begin{array}{l}\text { Treating heartburn, hepatitis, } \\
\text { speeding up postpartum } \\
\text { recovery, treating swelling due } \\
\text { to impact }\end{array}$ \\
\hline & $\begin{array}{l}\text { Bongah raya } \\
\text { hitam }\end{array}$ & $\begin{array}{l}\text { Curcuma aeruginosa } \\
\text { Roxb. }\end{array}$ & Rhizome & Mashed, boiled, drunk & Treating cough \\
\hline & $\begin{array}{l}\text { Bongah raya } \\
\text { kunyit }\end{array}$ & Curcuma amada Roxb. & Rhizome & Mashed, boiled, drunk & Treating hepatitis \\
\hline & $\begin{array}{l}\text { Bongah raya } \\
\text { putih }\end{array}$ & $\begin{array}{l}\text { Curcuma zedoaria } \\
\text { Roxb. }\end{array}$ & Rhizome & Mashed, boiled, drunk & Treating worms \\
\hline & Longkas & $\begin{array}{l}\text { Alpinia galanga }(\mathrm{L} .) \\
\text { Willd. }\end{array}$ & Rhizome & Pounded, smeared & $\begin{array}{l}\text { Treating ringworm, scabies } \\
\text { and Pityriasis versicolor }\end{array}$ \\
\hline & $\begin{array}{l}\text { Loyak } \\
\text { joronang }\end{array}$ & $\begin{array}{l}\text { Zingiber officinale } \\
\text { Roscoe. }\end{array}$ & Rhizome & $\begin{array}{l}\text { Pounded, mixed water, } \\
\text { drunk }\end{array}$ & $\begin{array}{l}\text { Treating swelling from injury } \\
\text { and postpartum recovery }\end{array}$ \\
\hline & Tabau & Kaempferia galanga $\mathrm{L}$. & Rhizome & Pounded, smeared & Treating colds in babies \\
\hline
\end{tabular}

Dayak Jangkang people use Alpinia galanga for ringworm, scabies, and Pityriasis versicolor drugs. Curcuma aeruginosa for cough medicine. Curcuma amada for hepatitis medication. Curcuma domestica heartburn medication, hepatitis, accelerates postpartum recovery, treats swelling due to impact; Curcuma zedoaria to treat worms; Kaempferia galanga to treating colds in babies; and Zingiber officinale to treat swelling due to injury and postpartum recovery. Verma et al. (2011) revealed that $A$. galanga has been recognized for traditional medicine as antifungal, antitumor, antidiuretic, heart disease, rheumatism, chest pain, fever, diabetes, liver disease, and kidney. Reanmongkol et al. (2006) reported that $C$. aeruginosa is used as a prescription component of traditional medicine because it has antipyretic and antiinflammatory activity. Policegoudra et al. (2011) wrote that $C$. amada could cure itching, skin diseases, bronchitis, asthma, and inflammation due to injury because it has biological activities including antioxidants, antibacterial, antiinflammatory, antifungal, inhibition of platelet aggregation, and analgesics. Muniyappan and Nagarajan (2014) reported that $C$. domestica has biological activity such as antibacterial, antiinflammatory, and good antioxidants. Chen et al. (2011) reported that $C$. zedoaria could be used for traditional herbs because it presents antiangiogenic activity capable of suppressing the growth of melanoma and lung metastasis. Labrooy et al. (2018) mentioned that $K$. galanga is widely used as ethnomedicinal. John et al. (2021) reported that $Z$. officinale plays a role in reducing some types of cancer, diabetes, and blood pressure because it has antiinflammatory properties.

Dayak Jangkang people also utilized plants from the Lamiaceae family for traditional medicine. The Lamiaceae family used by the Dayak Jangkang tribe were Orthosiphon stamineus for kidney pain drugs and difficulty defecating; Premna cordifolia to treat body odor; Vitex pinnata for headache medication; Ocimum basilicum to treat Pityriasis versicolor, scabies, and ringworm; and Premna cordifolia to treat inflammation, stomach upsets, wound healing, skin diseases, and immune-related diseases (Dianita and Jantan 2017. Also, V. pinnata for postnatal herbal baths, treating jaundice and abdominal pain (Goh et al. 2017). Orthosiphon stamineus contains phenolic compounds and flavonoids that serve as antioxidants, antimicrobials, and anti-proliferative (Ashraf et al. 2020) and treat glucose intolerance in pregnancy (Lokman et al. 2019). Ocimum basilicum contains phenolic compounds, is rich in antioxidants, has an inhibitory effect on bacterial growth (Gürgan and Adiloğlu 2021), and is used as antidiabetic (Othman et al. 2021).

The Dayak Jangkang tribe also used plants from the family Piperaceae for traditional medicine. Piper is an important medicinal plant used in various systems of medicine (Naim and Mahboob 2020). The species of Piperaceae are widely used for antibacterial, antifungal, and antiprotozoal (Oyedeji et al. 2005; Sauter et al. 2012). Arunachalam et al. (2020) reported that Piper is widely 
used as a folk remedy to treat gastrointestinal, gastroprotective, and inflammatory disorders. Alves et al. (2019) said that Piper is popularly used to treat various health conditions such as abdominal pain, skin sores, measles, and kidney problems. The plants of the Piperaceae family used by the Dayak Jangkang tribe were Piper betle to treat blurred eyes, $P$. crocatum to treat jaundice/liver/hepatitis, and $P$. nigrum to treat colds.

Piper betle has been used as a folk remedy because it has a fabulous stimulating effect on the pancreas, improves digestion, helps cure lung diseases, and constipation (Thịa et al. 2021). The plant contains bio-compounds, such as antibacterial, antiinflammatory, antioxidant, and anticancer, and has positive effects in treating diabetes and burns (Durani et al. 2017; Majumdar and Subramanian 2019). Piper crocatum is one of the popular traditional herbal remedies and empirically has been empirically used as an herbal remedy to treat diabetic wounds (Setyawati et al. 2021), coroner heart disease prevention, and contains biological activities as antihyperglycemic, antiproliferative, and antiinflammatory (Arbain et al. 2018). Piper nigrum exhibit various biological activities such as antihypertensive, antioxidant, antitumor, antiasthma, analgesic, antiinflammatory, antidiarrheal, antispasmodic, antidepressant, immunomodulator, anticonvulsant, antithyroid, antibacterial, and antifungal (Damanhouri and Ahmad 2014).

Dayak Jangkang people used plants from the Poaceae family to treat various diseases traditionally. Imperata cylindrica is used to treat sore throats; Cymbopogon citratus is used to treat cough; and Cymbopogon nardus is to treat colds. Rong-hua et al. (2013) reported that $I$. cylindrica is a popular herbal remedy used as a diuretic and antiinflammatory agent. $\mathrm{Li}$ et al. (2021) reported that $C$. citratus is used in local and traditional medicine to treat inflammatory diseases. Kumar et al. (2021) also reported that the plant is a perennial herb that has been widely consumed for traditional medicine. Saputra et al. (2020) reported that $C$. nardus is one of the medicinal plants containing active compounds of essential oils that serve as antioxidants and antifungals.

Dayak Jangkang people also utilized plants from the Araceae family. The family contains alkaloids, flavonoids, and polyphenols (Iwashina et al. 2020). Plants within the family are rich in bioactive compounds of specific secondary metabolites such as alkaloids, flavonoids, tannins, and polyphenols. The plants contain various biological effects and are used as a traditional medicine to cure various diseases (Cahyaningsih et al. 2021; Prasathkumar et al. 2021). Alkaloids provide antioxidant, antidiabetic, antimicrobial, antiinflammatory, and anticancer (Kukulka-Koch and Widelski 2017; Singh et al. 2021). Flavonoids show excellent antifungal activity (Ahmed et al. 2017), besides tannins have antiinflammatory, and antioxidant pharmacological activity (Xiong et al. 2021). Polyphenols have biological activity for antioxidants, antiinflammatory, antimicrobial, and antidiabetics (Lescano et al. 2019). The plant species of the Araceae family used by the Dayak Jangkang tribe were Homalomena occulta to treat venomous animal bites and
Xanthosoma sagittifolium to treat hypertension. Homalomena occulta is used medically to treat fractures, abdominal pain, and intestinal parasites (POWO 2021). In addition, $X$. sagittifolium has antimicrobial, antioxidant, antidiabetic, and hypolipidaemic (Hossain et al. 2017).

The Dayak Jangkang tribe utilized roots, bulbs, rhizomes, stems, bark, hump, fruit, fruit skins, leaves, fruits, and seeds to treat diseases. We obtained that the Dayak Jangkang tribe utilized plant organs through traditions that have long been carried out, through previous parents orally, and even dream. According to Julung et al. (2018) and Supiandi and Leliavia (2020), public knowledge related to the use of plants for medicine is obtained from ancestors through dreams and from parents delivered orally. Garvita (2015) mentioned that the traditions and knowledge of rural local people about the use of medicinal plants could not be separated from the local culture that has been practiced for a long time.

The results of previous studies mentioned several reasons for the use of plant organs (roots, stems, leaves, flowers, fruit, seeds) in the treatment of diseases traditionally as follows. Roots have high efficacy in medicine if accompanied by certain incantations (Supiandi et al. 2020). Stems as a place of food hoarding, so that contain many substances that are good for the body (Sofiah 2014), leaves contain secondary metabolite compounds such as flavonoids, saponins, tannins, alkaloids, and morphine that serve as drugs (Lee et al. 2014; Ahmad et al. 2015). Flowers contain steroid, terpenoid, and phenolic compounds that act as antiinflammatory, antibacterial, and antimicrobial activities (Oktavia 2015). Fruit as a source of vitamins and minerals (Tarwotjo 1998), seeds containing secondary metabolite compounds of alkaloids, flavonoids, terpenoids, polyphenols, phenolic hydroquinone, and saponins (Adawiah 2016). In general, the active compounds that found in plant organs in the form of secondary metabolites could act as antiviral, anticancer, antiinflammatory, antioxidant, anti hepatoxic, and antidiabetic (Adfa 2005).

Dayak Jangkang people employed a simple mode of preparation, i.e., pounded and smeared, pounded and taped, chopped, boiled and drunk, boiled and eaten, mashed, mixed with water and drunk, pounded, mixed with water and dripped. The reasons people use these methods are (i) not challenging to do, (ii) do not require expensive tools, (iii) the cost is cheap, (iv) anyone can do it. Previous studies also revealed that Dayak people generally process medicinal plants easily and simply (Adyana 2012; Supiandi et al. 2019). Another study reported that the way plants are used by pounding and smeared generally treats external diseases and reacts when applied to the sick part (Efremila et al. 2015). The treatment process by taping will accelerate the response of drugs in the sick body (Nurhaida et al. 2015). The boiling process can produce active substances; in other words, it can increase antioxidants activity (Uzlifah 2014). The preparation mode through boiled and then eaten generally treats internal diseases and positively impacts healing (Syah et al. 2014).

The knowledge of Dayak Jangkang people about using plants to treat various diseases needs to be practiced 
continuously and passed down to the younger generation. This phenomenon is an effort to maintain local people's knowledge about medicinal plants and the cultural identity of the local community so that they will not become extinct. The effort is also part of introducing locally used medicinal plants to the broader audience because medicinal plants are valuable for people in need. Cahyaningsih et al. (2021) mentioned that medicinal plants are valid and useful.

\section{ACKNOWLEDGEMENTS}

We conveyed the thanks to the Ministry of Research and Technology/National Research and Innovation Agency for fund assistance through contract number: 001/B10/H5/VII/2021.

\section{REFERENCES}

Adawiah. 2016. Kandungan fitokimia dan bioaktivitas ekstrak metanol biji palem putri (Veitchia merillii). J Kimia Valensi: J Penelitian dan Pengembangan Ilmu Kimia 2 (1): 63-70. DOI: 10.15408/jkv.v2i1.3076. [Indonesian]

Adfa M. 2005. Survey etnobotani, studi senyawa flavonoid dan uji brine shrimp beberapa tumbuhan obat tradisional Suku Serawai di Propinsi Bengkulu. J Gradien 1 (1): 43-50. [Indonesian]

Adyana M. 2012. Cara pengolahan obat tradisional baik dan benar. Retrieved from http://www.herbaltarupratama.com/artikel-18. [Indonesian]

Ahmad A, Kaleem M, Ahmed Z, Shafiq H. 2015. Therapeutic potential of flavonoids and their mechanism of action against microbial and vira infections-A review. Food Res Intl 77 (2): 221-235. DOI: 10.1016/j.foodres.2015.06.021

Ahmed E, Arshad M, Zakriyya KM, Shoaib AH, Mehreen SH, Riaz I, Sabir S, Ahmad N, Sabaoon MA. 2017. Secondary metabolites and their multidimensional prospective in plant life. J Pharmac Phytochem 205: 205-214.

Ajesh TP, Naseef SAS, Kumuthakalavalii R. 2012. Ethnobotanical documentation of wild edible fruit use by Muthuvan Tribe of Idduki, Kerala-India. Intl J Pharm Sci 3 (3): 479-467.

Akgul A, Akgul A, Senol GS, Yildirim H, Secmen O, Dogan Y. 2018. An ethnobotanical study in Midyat (Turkey), a city on the silk road where cultures meet. J Ethnobiol Ethnomed 14 (12): 1-18. DOI: 10.1186/s13002-017-0201-8.

Albuquerque UP, Lucens RFP, Monteiro JM, Florentino ATN, Almeida CF. 2006. Evaluating two quantitative ethnobotanical techniques. J Ethnobot Res Appl 4: 051-060. DOI: 10.17348/era.4.0.51-60.

Alloy S, Albertus, Yovinus, Istiyani CP. 2008. Peta Keberagaman Subsuku Dayak di Kalimantan Barat. Dayakologi Institute, Pontianak. [Indonesian]

Alves NSF, Setzer WN, da Silva JKR. 2019. The chemistry and biological activities of Peperomia pellucida (Piperaceae): A critical review. J Ethnopharmacol 232: 90-102. DOI: 10.1016/j.jep.2018.12.021.

Anand U, Tudu CK, Nandy S, Sunita K, Tripathi V, Loake GJ, Dey A, Prockow J. 2021. Ethnodermatological use of medicinal plants in India: From ayurvedic formulations to clinical perspective-A review. J Ethnopharmacol 284: 1-28. DOI: 10.1016/j.jep.2021.114744.

Andesmora VE, Muhadiono, Hilwan I. 2017. Ethnobotanical study of plants used by people in Hiang indigenous forest Kerinci, Jambi. J Trop Life Sci 7 (2): 95-101. DOI: 10.11594/jtls.07.02.02.

Arbain D, Nofrizal, Syafni N, Ismed F, Yousuf S, Choudhary MI. 2018. Bicyclo [3.2.1] octanoid neolignans from Indonesian red betle leaves (Piper crocatum Ruiz \& Pav.). Phytochem Lett 24: 163-166. DOI: 10.1016/j.phytol.2018.02.006.

Arunachalam K, Damazo AS, Macho A, Lima JCD, Pavan E, Figueiredo FD, Oliveira DM, Cechinel-Filho V, Wagner TM, Martins DTD 2020. Piper umbellatum L. (Piperaceae): Phytochemical profiles of the hydroethanolic leaf extract and intestinal antiinflammatory mechanisms on 2,4,6 trinitrobenzene sulfonic acid induced ulcerative colitis in rats. J Ethnopharmacol 254: 1-13. DOI: 10.1016/j.jep.2020.112707.

Ashraf K, Halim H, Lim SM, Ramasamy K, Sultan S. 2020. In vitro antioxidant, antimicrobial and antiproliferative studies of four different extracts of Orthosiphon stamineus, Gynura procumbens and Ficus deltoidea. Saudi J Biol Sci 27 (1): 417-432. DOI: 10.1016/j.sjbs.2019.11.003

Bernard HR. 2002. Research Methods in Anthropology: Qualitative and Quantitative Approaches. 3rd ed. Alta Mira Press, Walnut Creek, CA.

Byg A, Baslev H. 2001. Diversity and use de palms in Zahamena, Esatern Madagaskar. Biodivers Conserv 10: 951-970. DOI: 10.1023/A:1016640713643.

Cahyaningsih R, Brehm JM, Maxted N. 2021. Gap analysis of Indonesian priority medicinal plant species as part of their conservation planning. Glob Ecol Conserv 26: 1-11. DOI: 10.1016/j.gecco.2021.e01459.

Chen W, Lu Y, Gao M, Wu J, Wang A, Shi R. 2011. Anti-angiogenesis effect of essential oil from Curcuma zedoaria in vitro and in vivo. $\mathbf{J}$ Ethnopharmacol 133: 220-226. DOI: 10.1016/j.jep.2010.09.031.

Damanhouri Z, Ahmad A. 2014. A Review on therapeutic potential of Piper nigrum L. (Black pepper): The king of spices. Med Aromat Plants 3: 161. DOI: 10.4172/2167-0412.1000161.

De la Torre L, Ceron CE, Balslev H, Borchsenius F. 2012. A biodiversity informatics approach to ethnobotany: Meta-analysis of plants use patterns in Educator. Ecol Soc 17 (1): 15-31. DOI: 10.5751/ES$04582-170115$

Dianita R, Jantan I. 2017. Ethnomedicinal uses, phytochemistry and pharmacological aspects of the genus Premna: A review. Pharm Biol 55 (1): 1715-1739. DOI: 10.1080/13880209.2017.1323225.

Direktorat Jenderal Kependudukan dan Pencatatan Sipil. 2020. Data Kependudukan Desa Benua Kecamatan Jangkang Kabupaten Sanggau. Retrieved from http://data.kalbarprov.go.id/dataset/datakependudukan-desa-benua-kecamatan-jangkang-kabupaten-sanggau30-juni-2020. [Indonesian]

Durani LW, Khor SC, Tan JK, Chua KH, Yusof YAM, Makpol S. 2017. Piper betle L. modulates senescence-associated genes expression in replicative senescent human diploid fibroblasts. BioMed Res Intl 2017 (7): 1-9. DOI: 10.1155/2017/6894026.

Efremila, Wardenaar E, Sisilia L. 2015. Studi etnobotani tumbuhan obat oleh suku etnis Dayak di Desa Kayu Tanam Kecamatan Mandor Kabupaten Landak Kalimantan. J Hutan Lestari 3 (2): 234-246. [Indonesian]

Fadilah, Lovadil L, Linda R. 2015. Pemanfaatan tumbuhan dalam pengobatan tradisional masyarakat suku Dayak Kanayatn di Desa Ambawang Kecamatan Kubu Kabupaten Kubu Raya. Protobiont 4 (3): 49-59. [Indonesian]

Garvita RV. 2015. Pemanfaatan tumbuhan obat secara tradisional untuk memperlancar persalinan oleh suku Dayak Meratus di Kalimantan Selatan. Warta Kebun Raya 13 (2): 51-58. [Indonesian]

Goh MPY, Basri AM, Yasin H, Taha H, Ahmad N. 2017. Ethnobotanical review and pharmacological properties of selected medicinal plants in Brunei Darussalam: Litsea elliptica, Dillenia suffruticosa, Dillenia excels, Aidia racemosa, Vitex pinnata and Senna alata. Asian Pac J Trop Biomed 7 (2): 173-180. DOI: 10.1016/j.apjtb.2016.11.026.

Gürgan M, Adiloğlu S. 2021. Increasing concentrations of iron fertilizer affect antibacterial activity of basil (Ocimum basilicum L.). Ind Crops Prod 170: 1-6. DOI: 10.1016/j.indcrop.2021.113768.

Gurib-Fakim A. 2006. Medicinal plants: Traditions of yesterday and drugs of tomorrow. Mol Asp Med 27: 1-9. DOI: 10.1016/j.mam.2005.07.008.

Habsah M, Amran M, Mackeen MM, Lajis NH, Kikuzaki H, Nakatani N, Rahman AA and Ali AM. 2000. Screening of Zingiberaceae extracts for antimicrobial and antioxidant activities. J Ethnopharmacol 72: 403-410. DOI: 10.1016/S0378-8741(00)00223-3.

Hossain MS, Uddin MS, Asaduzzaman M, Munira MS, Uddin MJ, Rafe MR, Rahman MM. 2017. Inquiry of analgesic and antiinflammatory activities of Xanthosoma sagittifolium L.: An effective medicinal plant. J Coast Life Med 5 (1): 22-26. DOI: 10.12980/jclm.5.2017J6229.

Iwashina T, Destari, Rahayu S, Tsutsumi C, Yuzammi, Mizuno T, Widyatmoko D. 2020. Flavonoids and xanthones from the leaves of Amorphophallus titanium (Araceae). Biochem Sys Ecol 90: 1-3. DOI: 10.1016/j.bse.2020.104036.

Jitoe A, Masuda T, Mabry TJ. 1994. Novel antioxidants, cassumunarin A, B, and C, from Zingiber cassumunar. Tetrahedron Lett 35(7): 981984. DOI: 10.1016/S0040-4039(00)79944-8 
John JC, Mallikarjunaswamy GE, Noushad N. 2021. Probiotic rhizospheric Bacillus sp. from Zingiber officinale Rosc. displays antifungal activity against soft rot pathogen Pythium sp. Curr Plant Biol 27: 1-7. DOI: 10.1016/j.cpb.2021.100217.

Julung H, Supiandi MI, Ege B, Mahanal S, Zubaidah S. 2018. Analisis sumber pengetahuan tradisional tanaman obat yang digunakan oleh masyarakat suku Dayak Desa. Proc Biol Educ 2 (1): 67-74. DOI: 10.21009/pbe.2-1.9. [Indonesian]

Kabir SMS. 2016. Methods of Data Collection. Curtin University, Perth, Australia.

Kewessa G, Abebe T, Demessie A. 2015. Indigenous knowledge on the use and management of medicinal trees and shrubs in Dale District, Sidama Zone, Southern Ethiopia. Ethnobot Res Appl 14: 171-182. DOI: $10.17348 /$ era.14.0.171-182.

Kukulka-Koch WA, Widelski J. 2017. Alkaloids. Pharmacognosy 2017: 163-198. DOI: 10.1016/B978-0-12-802104-0.00009-3.

Kumar A, Dev K, Sourirajan A. 2021. Essential oils of Rosmarinus officinalis L., Cymbopogon citratus (DC.) Stapf., and the phytocompounds, delta-carene and alpha-pinene mediate cell cycle arrest at G2/M transition in budding yeast Saccharomyces cerevisiae. S Afr J Bot 141: 296-305. DOI: 10.1016/j.sajb.2021.05.008.

Kustiawan W. 2007. Medicinal plants of Kalimantan forest: A review. Nat Life 2 (1): 27-34.

Labrooy CD, Abdullah TL, Stanslas J. 2018. Identification of ethnomedicinally important Kaempferia L. (Zingiberaceae) species based on morphological traits and suitable DNA region. Curr Plant Biol 14: 50-55. DOI: 10.1016/j.cpb.2018.09.004.

Laokor N, Juntachai W. 2021. Exploring the antifungal activity and mechanism of action of Zingiberaceae rhizome extracts agains Malassezia furfur. J Ethnopharmacol 279: 1-7. DOI 10.1016/j.jep.2021.114354.

Lee ST, Welch KD, Panter KE, Gardner DR, Garrossian M, Chang CT. 2014. Cyclopamine: From cyclops lambs to cancer treatment. J Agric Food Chem 62 (30): 7355-7362. DOI: 10.1021/jf5005622.

Lescano CH, de Lima FF, Caires ARL, de Oliveira P. 2019. Polyphenols Present in Campomanesia Genus: Pharmacological and Nutraceutical Approach. Polyphenols in Plants (Second Edition). Elsevier, Amsterdam. DOI: 10.1016/B978-0-12-813768-0.00027-X

Li C, Luo Y, Zhang W, Cai Q, Wu X, Tan Z, Chen R, Chen Z, Wang S, Zhang L. 2021. A comparative study on chemical compositions and biological activities of four essential oils: Cymbopogon citratus (DG.) Stapf, Cinnamomun cassia (L.) Presl, Salvia japonica Thunb. and Rosa rugosa Thunb. J Ethnopharmacol 280: 1-10. DOI: 10.1016/j.jep.2021.114472.

Lokman EF, Saparuddin F, Muhammad H, Omar MH, Zulkapli A. 2019. Orthosiphon stamineus as a potential antidiabetic drug in maternal hyperglycemia in stretozotocin-induced diabetic rats. Integr Med Res 8 (3): 173-179. DOI: 10.1016/j.imr.2019.05.006.

Majumdar AG, Subramanian M. 2019. Hydroxychavicol from Piper betle induces apoptosis, cell cycle arrest, and inhibits epithelialmesenchymal transition in pancreatic cancer cells. Biochem Pharmacol 166: 274-291. DOI: 10.1016/j.bcp.2019.05.025.

Marin EA, Lima JRF, Palma ART, de Lucena RFP, and de Cruz DD 2015. Traditional knowledge in rural community in the Semi-Arid Region on Brazil: Age and gender patterns and their implications for plant conservation. Ethnobot Res Appl 14: 331-344. DOI: 10.17348/era.14.0.331-344

Miles MB, Huberman AM. 2007. Qualitative Data Analysis. UI Press, Jakarta.

Muniyappan N, Nagarajan NS. 2014. Green synthesis of gold nanoparticles using Curcuma psedomontana essential oil, its biological activity and cytotoxicity against human ductal breast carcinoma cells T47D. J Environ Chem Eng 2 (4): 2037-2044. DOI: 10.1016/j.jece.2014.03.004.

Muthu C, Ayvanar M, Raja M, Ignacimuthu S. 2006. Medicinal plants used by traditional healers in Kancheepuram district of Tamil Nadu, India. J Ethnobiol Ethnomed 2: 1-10. DOI: 10.1186/1746-4269-2-43.

Nahdi MS, Martiwi INA, Arsyah DC. 2016. The ethnobotany of medicinal plants in supporting the family health in Turgo, Yogyakarta, Indonesia. Biodiversitas 17 (2): 900-906. DOI 10.13057/biodiv/d170268.

Naim DM, Mahboob S. 2020. Molecular identification of herbal species belonging to genus Piper within family Piperaceae from Northern Peninsular Malaysia. J King Saud Univ Sci 32 (2): 1417-1426. DOI: 10.1016/j.jksus.2019.11.036
Namsa ND, Mandal M, Tangjang S, Mandal SC. 2011. Ethnobotany of the Monpa ethnic group at Arunachal Pradesh, India. J Ethnobiol Ethnomed 7: 20-31. DOI: 10.1186/1746-4269-7-31.

Nurcahyani I, Daling S, Ismawati I, Supiandi MI. 2019. Ethnobotany and conservation perspective based on local wisdom in Dayak Taman tribe, West Kalimantan, Indonesia. Intl J Acad Res Dev 4 (4): 27-35.

Nurhaida, Usman FH, dan Tavita GE. 2015. Studi etnobotani tumbuhan obat di Dusun Kelampuk kecamatan Tanah Pinoh Barat Kabupaten Melawi. J Hutan Lestari 3 (4): 526-537. [Indonesian]

Oktavia J. 2015. Profil Fitokimia pada Bunga Tanaman Kembang Kertas (Bougainvillea sp.). [Skripsi]. Universitas Tarumanagara, Jakarta. [Indonesian]

Othman MS, Khaled AM, Al-Bagawi AH, Fareid MA, Ghany RA, Habotta OA, Moneim AEA. 2021. Hepatorenal protective efficacy of flavonoids from Ocimum basilicum extract in diabetic albino rats: A focus on hypoglycemic, antioxidant, antiinflammatory and antiapoptotic activities. Biomed Pharmacother 144: 1-13. DOI: 10.1016/j.biopha.2021.112287.

Oyedeji OA, Adeniyi BA, Ajayi O, König WA. 2005. Essential oil composition of Piper guineense and its antimicrobial activity: Another chemotype from Nigeria. Phytother Res 19 (4): 362-364. DOI: $10.1002 /$ ptr.1679.

Ozaki Y, Kawahara N and Harada M. 1991. Antiinflammatory effect of Zingiber cassumunar Roxb. and its active principles. Chem Pharmac Bull 39 (9): 2353-2356. DOI: 10.1248/cpb.39.2353.

Policegoudra RS, Aradhya SM, Singh L. 2011. Mango ginger (Curcuma amada Roxb.) - A promising spice for phytochemicals and biological activities. J Biosci 36: 739-748. DOI: 10.1007/s12038-011-9106-1.

POWO. 2021. Plants of the World Online. Facilitated by the Royal Botanic Garden, Kew. http://www.plantsoftheworldonline.org/

Prasathkumar M, Anisha S, Dhrisya C, Becky R, Sadhasivam S. 2021. Therapeutic and pharmacological efficacy of selective Indian medicinal plants- A review. Phytomed Plus 1 (2): 1-8. DOI: 10.1016/j.phyplu.2021.100029.

Purwoko A. 2004. Identifikasi tumbuhan sumber pangan, obat-obatan dan biopestisida serta tingkat pemanfaatannya di Suaka Margasatwa Karang Gading dan Langkat Timur Laut. J Komunikasi Penelitian 16 (6): 97-104. [Indonesian]

Rashid N, Gbedomon CR, Ahmad M, Salako KV, Zafar M, Malik K. 2018. Traditional knowledge on herbal drinks among indigenous communities in Azad Jammu and Kashmir, Pakistan. J Ethnobiol Ethnomed 14 (16): 1-20. DOI: 10.1186/s13002-018-0217-8.

Reanmongkol W, Subhadhirasakul S, Khaisombat N, Fuengnawakit P, Jantasila S, Khamjun A. 2006. Investigation the antinociceptive, antipyretic and antiinflammatory activities of Curcuma aeruginosa Roxb extracts in experimental animal. Songklanakarin J Sci Technol 28 (5): 99-108.

Rong-hua L, Shi-sheng C, Gang R, Feng S, Hui-lian H. 2013. Phenolic compounds from roots of Imperata cylindrical var. major. Chin Herb Med 5 (3): 240-243. DOI: 10.3969/j.issn.1674-6348.2013.03.011.

Roslinda E. 2016. Dayak Desa forest land use system as social capital to acquire forest management rights in West Kalimantan, Indonesia. Biodiversitas 7 (1): 177- 184.

Saputra NA, Wibisono HS, Darmawan S, Pari G. 2020. Chemical composition of Cymbopogon nardus essential oil and its broad spectrum benefit. IOP Conf Ser Earth Environ Sci 415: 1-7. DOI: 10.1088/1755-1315/415/1/012017

Sardana A, Hernawati J, Dharma NGG, Nugroho AE, Aliyah N. 2011. Potret Provinsi Kalimantan Barat. BPKN Wilayah III Pontianak, Pontianak. [Indonesian]

Sartini. 2004. Menggali kearifan lokal nusantara sebuah kajian filsafat. J Filsafat 37 (2): 111-120. [Indonesian]

Sauter IP, Rossa GE, Lucas AM, Cibulski SP, Roehe PM, da Silva LAA, Rott MB, Vargas RMF, Cassel E, von Poser GL. 2012. Chemical composition and amoebicidal activity of Piper hispidinervum (Piperaceae) essential oil. Ind Crop Prod 40: 292-295. DOI: 10.1016/j.indcrop.2012.03.025.

Setyawan AD. 2010. Biodiversity conservation strategy in a native perspective case study of shifting cultivation at the Dayaks of $\begin{array}{llll}\text { Kalimantan. Nusantara Biosci 2: 97-108. DOI: } & \end{array}$ 10.13057/nusbiosci/n020208.

Setyawati A, Wahyuningsih MSH, Nugrahaningsing DAA, Effendy C, Fneish F, Fortwengel G. 2021. Piper crocatum Ruiz \& Pav. ameliorates wound healing through p53, E-cadherin and SOD1 pathways on wounded hyperglycemia fibroblasts. Saudi J Biol Sci 28: 7257-7268. DOI: 10.1016/j.sjbs.2021.08.039. 
Simamora EW. 2018. Potensi Tumbuhan Obat di Kawasan Hutan Lindung Harangan Bolak Kabupaten Samosir Provinsi Samosir. [Skripsi]. Universitas Sumatera Utara, Sumatera Utara. [Indonesian]

Singh S, Pathak N, Fatima E, Negi AS. 2021. Plant isoquinoline alkaloids: Advances in the chemistry and biology of berberine. Eur J Med Chem 226: 1-26. DOI: 10.1016/j.ejmech.2021.113839.

Sirirugsa P. 1998. Thai Zingiberaceae: Species diversity and their uses. The International Conference on Biodiversity and Bioresources: Conservation and Utilization. Phuket, Thailand, 23-27 November 1997.

Sofiah W. 2014. Studi Etnobotani Tumbuhan Obat pada Masyarakat Kecamatan Arjasa Kepulauan Kangean Kabupaten Sumenep Madura. [Skripsi]. Universitas Islam Negeri Maulana Malik Ibrahim, Malang. [Indonesian]

Sop TKJ, Oldeland F, Bognounou U, Scmiedel, Thiombiano A. 2012. Ethnobotanical knowledge and valuation of woody plants species: A comparative analysis of three ethnic groups from the Sub-Sahel of Burkina Faso. Environ Sustain 14: 627-649. DOI: 10.1007/s10668012-9345-9.

Suhartini. 2009. Kajian Kearifan Lokal Masyarakat dalam Pengelolaan Sumberdaya Alam dan Lingkungan. Universitas Negeri Yogyakarta, Yogyakarta. [Indonesian]

Suparmini, Setyawati S, Sumunar DRS. 2013. Pelestarian lingkungan masyarakat Baduy berbasis kearifan lokal. J Penelitian Humaniora 18 (1): 8- 22 .

Supiandi MI, Leliavia. 2020. The source traditional medication knowledge: The Dayak Iban in Lanjak Deras Village. J Pendidikan Biologi 5 (2): 184-192. DOI: 10.31932/jpbio.v5i2.751.

Supiandi MI, Julung H, Ege B, Mahanal S, Zubaidah S. 2020. Potential of plant roots as traditional medicines of the Dayak Desa Tribe in Pakak, West Kalimantan, Indonesia. Med Plants 12 (2): 275-282. DOI: 10.5958/0975-6892.2020.00036.2.

Supiandi MI, Zubaidah S, Mahanal S, Julung H, Ege B. 2019. An ethnobatical study of medicinal plants used by Dayak Desa from
Tintau Menuah forest and Genik Luak Bukit Bang. Med Plants 11 (3): 292-306. DOI: 10.5958/0975-6892.2019.00038.8.

Syah J, Usman FH, Yusro F. 2014. Studi etnobotani tumbuhan obat yang di manfaatkan masyarakat Dusun Nekbare Desa Babane Kecamatan Samalantan Kabupaten Bengkayang. J Hutan Lestari 2 (3): 419-426. [Indonesian]

Takoy DM, Linda R, Lovadi I. 2013. Tumbuhan berkhasiat obat suku dayak seberuang di kawasan hutan Desa Ensabang Kecamatan Sepauk Kabupaten Sintang. Protobiont 2 (3): 122-128. [Indonesian]

Tarwotjo S. 1998. Dasar-Dasar Gizi Kuliner. PT Gramedia Widiasarana Indonesia, Jakarta. [Indonesian]

Thịa C, Nguyễn H, Hoang DM. 2021. Influence of Piper betle L. extract on umbilical cord cells in vitro and potential treating cutaneous wound. Heliyon 7: 1-8. DOI: 10.1016/j.heliyon.2021.e06248.

Tropical Plant Curriculum (TPC). 2012. Tanaman Obat Herba Berakar Rimpang. IPB University, Bogor. [Indonesian]

Uzlifah U. 2014. Aktivitas Antioksi dan Sirup Kombinasi Daun Sirsak (Anona muricata) dan Kulit Buah Naga (Hylocereus costaricensis) dengan Variasi Lama Perebusan. [Skripsi]. Universitas Muhammadiyah, Surakarta. [Indonesian]

Verma RK, Mishra G, Singh P, Jha KK, Khosa RL. 2011. Alpinia galangal- An important medicinal plant: A review. Der Pharmacia Sinica 2 (1): 142-154

Virginia ND. 2006. Local Knowledge and Memory in Biodiversity Conservation. Department Anthropology, Athens Feorgia, Georgia

Xiong P, Qin S, Li K, Liu M, Zhu L, Peng J, Shi S, Tang S, Tian A, Cai W. 2021. Identification of the tannins in traditional Chinese medicine Paeonie Radix Alba by UHPLC-Q-Exactive Orbitrap MS. Arab J Chem 14 (11): 1-14. DOI: 10.1016/j.arabjc.2021.103398.

Yusro, Fathul, Mariani Y, Diba F, Ohtani K. 2014. Inventory of medicinal plants for fever used by four Dayak Sub Ethnic in West Kalimantan, Indonesia. Kuroshio Sci 8 (1): 33-38. 